\title{
Effects of seasonality and moult cycle on the proliferation of nerve cells and on the labelling of ecdysone receptors in an estuarine crab
}

\author{
Gabriela Hollmann • Duane Barros Fonseca • \\ Silvana Allodi · Pablo Elías Martinez • \\ Luiz Eduardo Maia Nery
}

Received: 14 May 2010/Revised: 4 November 2010/Accepted: 5 November 2010/Published online: 5 December 2010

(C) Springer-Verlag 2010

\begin{abstract}
Decapod crustaceans show proliferation of the nerve cells in the olfactory lobe throughout their lives. However, the regulation of this process is still poorly understood, since it may vary with endogenous and exogenous factors. The objective of the present investigation was to quantify the proliferation of nerve cells and number of nerve cells with ecdysone receptors in the clusters of the central olfactory system in Neohelice granulata, according to moult stages and in different seasons (summer and winter). Three injections of bromodeoxyuridine (BrdU) were administered to the crabs. Brains were sectioned by microtome and fixed on slides for immunohistochemistry with anti-BrdU and anti-EcR antibodies. The proliferation of nerve cells was higher in winter than in summer, probably because in winter the crabs do not breed and the premoult and postmoult periods are longer. Crabs in postmoult exhibited more BrdU-labelled cells than crabs in premoult or intermoult in winter, because of a greater number of mitoses related to an increase in body size and addition of olfactory receptor neurons. The number of EcRlabelled cells was higher in premoult than in postmoult or
\end{abstract}

G. Hollmann · D. B. Fonseca · P. E. Martinez ·

L. E. M. Nery $(\bowtie)$

Programa de Pós-Graduação em Ciências Fisiológicas:

Fisiologia Animal Comparada, Instituto de Ciências Biológicas,

Universidade Federal do Rio Grande-FURG, Av. Itália, km 8,

96201-900 Rio Grande, RS, Brazil

e-mail: nery@ octopus.furg.br

G. Hollmann

e-mail: gabrielahollmann@ufrj.br

\section{S. Allodi}

Programa de Pós-Graduação em Ciências Morfológicas, Instituto de Ciências Biomédicas, Universidade Federal do Rio de Janeiro, Av. Carlos Chagas Filho, 373, Ilha do Fundão,

21949-902 Rio de Janeiro, RJ, Brazil intermoult in winter. The proliferation of nerve cells is regulated seasonally and according to moult stages.

Keywords Proliferation of nerve cells $\cdot$ Ecdysone receptor $\cdot$ Neohelice granulata $\cdot$ Seasonality $\cdot$ Moult
Abbreviations
BrdU Bromodeoxyuridine
CM Mass cell (cluster)
EcR Ecdysone receptor
HHR Ecdysteroid responsive gene
OGT Olfactory globular tract
OL Olfactory lobe
ORN Olfactory receptor neurons
RT Room temperature
SEM Standard error

\section{Introduction}

Sensory and nervous systems gradually lose their functionality, generally over the lifespan of an animal. This loss may be related to the accumulation of oxidatively damaged molecules, which leads to dysfunction of metabolic and signalling pathways in neurons (Mattson et al. 2002). In insects, many age-related changes have been reported (Sohal 1983), such as a 33\% reduction in the number of brain cells in honeybees (Rockstein 1950), and shrinkage of the cortical area in fruit flies (Herman et al. 1971; Sohal and Sharma 1972). One way to offset these disorders is to produce new neurons. In mammals, restricted regions of the nervous system (viz, dentate gyros of hippocampus and the olfactory bulb) have normal proliferative capacity throughout adulthood (Emsley et al. 2005). 
Some findings indicate an interesting parallel between vertebrates and arthropods regarding the sites of proliferation in the nervous system. The current understanding regarding proliferation of nerve cells in the supraesophageal ganglion ('brain') has been gathered by the method of incorporation of $\mathrm{BrdU}$ (bromodeoxyuridine), which is also widely utilised in studies on vertebrates. Schmidt and Harzsch (1999) have demonstrated the occurrence of proliferation in cell clusters in the central olfactory system in crayfish.

Olfactory receptors are found on the first pair of antennae of decapods. Olfactory receptors are grouped in structures called aesthetascs, and their axons project ipsilaterally to the glomerular region of the olfactory lobe (OL), similarly to the glomerular region in the olfactory bulb of vertebrates (Mellon and Alones 1993). Cell clusters, which lie adjacent to the OL, are formed by small cell bodies ('globuli cells', typically $10 \mu \mathrm{m}$ in diameter) of projecting neurons. These cells send their axons bilaterally through the olfactory globular tract (OGT) to neuropils in the medulla terminalis of the lateral protocerebrum (Sullivan and Beltz 2001).

Even with advances in understanding the proliferation of nerve cells in decapod crustaceans, the regulation process is still poorly understood. An interesting step towards increasing comprehension of this regulation is to understand the variation of proliferation due to exogenous and endogenous changes. In some crustacean species, variations have been observed in nerve-cell proliferation of the olfactory central system. For instance, circadian changes in the rate of cell proliferation in the brain and antennules have been documented in spiny lobsters (Horner et al. 2003). Seasonal influences on neurogenesis are little understood, although a tendency towards fewer BrdU-labelled cells in winter than in summer has been observed in the eyestalk (hemiellipsoid body) of the crab Carcinus maenas (Hansen and Schimidt 2004). The rate of proliferation of nerve cells also varies with the stage of the moult cycle. For instance, the highest rate of neurogenesis in olfactory receptor neurons was found in the premoult, the lowest in the intermoult, and intermediate rates in the postmoult (Harrison et al. 2001).

In crustacean growth, size increases occur in 'jumps', because an animal must shed its exoskeleton to grow. As the animal grows, the antennae lengthen and more olfactory receptor neurons are added (Beltz and Sandeman 2003). The growth process comprises a moult cycle, which is dually controlled (Spaziani et al. 2001): negatively by the Moult Inhibitory Hormone, a neuropeptide produced and released by the $\mathrm{X}$ organ-sinus gland neuroendocrine complex that inhibits the $\mathrm{Y}$ organ, and positively by ecdysteroids produced and released by the $\mathrm{Y}$ organ. Ecdysone is secreted by the $\mathrm{Y}$ organ and is subsequently hydroxylated by target tissues to 20-hydroxyecdysone (Chang and Kaufman 2005), which is then transported through the haemolymph to target cells, where it binds to a heterodimeric receptor formed by two nuclear receptor superfamily members, the ecdysone receptor $(\mathrm{EcR})$ and the retinoid $\mathrm{X}$ receptor $(\mathrm{RXR} / \mathrm{ultraspi-}$ racle) (Tummel 1995). Ecdysteroids are main signalling molecules known to be involved with growth and proliferation in crustaceans. Actually, EcR regulates several physiological functions in development, reproduction, and metabolism in all arthropods studied so far (Nakagawa and Henrich 2009). The level of ecdysteroids in the haemolymph increases in early premoult, whereas during postmoult and intermoult, the level of ecdysteroids in the haemolyph is low in the crabs Callinectes sapidus (Soumoff and Skinner 1983) and Uca pugilator (Chung et al. 1998). In regenerating limb buds, hypodermis, and hepatopancreas of U. pugilator, EcR gene expression also increases significantly during premoult, but in gills, eyestalks, and muscle from nonregenerating walking legs and from the major cheliped there is no variation during the moult cycle (Chung et al. 1998). However, no information regarding location, quantity, or expression is available for EcR in the central olfactory system during the moult cycle and among seasons.

Crustaceans being ectotherms, their physiological processes are affected by temperature. The result is that growth and reproduction in decapods inhabiting subtropical regions are typically seasonal, as in summer these processes are more intense. For Neohelice granulata, a common salt-marsh crab in the Patos Lagoon estuary, the effects of seasonality on growth and reproduction have been characterised (Bas et al. 2009; Barutot et al. 2009). This species is active in summer, and in winter it remains longer in the burrows and its metabolic rate slows down (D'Incao et al. 1993; Monserrat and Bianchini 1995). Therefore, although the effects of seasonality on growth and reproduction are well documented in this species, the specific effects of seasonality on the proliferation of nerve cells are not known. Understanding the effects of seasonality is important, because nerve-cell proliferation might be related to general shifts in the physiology of individuals in the wild. Therefore, such an understanding would establish a link between mechanistic and environmental physiology. In the present investigation, we quantified the proliferation of nerve cells and of cells with ecdysone receptors in clusters of the central olfactory system of Neohelice granulata between summer and winter and among the different stages of the moult cycle.

\section{Materials and methods}

Collection and maintenance of crabs

Crabs (2.5-5.0 g) of N. granulata were caught in winter (September) and summer (January) in a salt-marsh in the 
Patos Lagoon estuary, and taken to the laboratory. In the laboratory, the animals were promptly injected with BrdU and kept in tanks with diluted seawater (salinity 20), controlled temperature $\left(20^{\circ} \mathrm{C}\right)$, and controlled photoperiod (12D:12L), and fed ad libitum with minced beef, during the remaining period of the experiment (see explanation below).

Experimental design, and schedule and procedures of BrdU injections

Crabs caught in each seasonal sampling period were divided into three groups according to the moult stage: premoult (group 1), postmoult (group 2), and intermoult (group 3). To determine the moult stage, a small piece of the telson was excised for observation of the setae under a microscope (setogenesis) (Chan et al. 1988; Cesar et al. 2006).

A total of three injections of $\mathrm{BrdU}$ (Sigma ${ }^{\circledR}$ B8434) solution were administered in the haemolymph of the animals of all groups. The first injection was given on the day of sampling, in late afternoon, by means of a Hamilton ${ }^{\circledR}$ syringe $(50 \mu \mathrm{m})$ attached to an insulin needle. The BrdU solution was injected at the base of either the fourth or fifth pair of pereopods. Following the first injection, two subsequent injections were administered in alternate shifts (second day in the morning, third day in the afternoon). The BrdU solution concentration was $10 \mathrm{mg} / \mathrm{ml}$ (Sullivan and Beltz 2005) in physiological solution, and the amount injected varied with the weight of the animal $(20 \mu \mathrm{l} / \mathrm{g}$ of body weight). The physiological solution contained $10 \mathrm{mMol} / 1 \mathrm{MgCl}_{2}, 355 \mathrm{mmol} / 1 \mathrm{NaCl}, 16.6 \mathrm{mmol} / 1 \mathrm{CaCl}_{2}$, $5 \mathrm{mmol} / 1 \mathrm{H}_{3} \mathrm{BO}_{3}, 10 \mathrm{mmol} / 1 \mathrm{KHCO}_{3}$, and $8 \mathrm{mmol} / 1$ $\mathrm{Na}_{3} \mathrm{C}_{6} \mathrm{H}_{5} \mathrm{O}_{7}-2 \mathrm{H}_{2} \mathrm{O}$ with pH adjusted to 7.6.

The supraesophageal ganglia of these individuals were removed $24 \mathrm{~h}$ after the last injection and fixed in paraformaldehyde (6 $\mathrm{h}$ in $4 \%$ paraformaldehyde solution, $\mathrm{pH} 7.4$ ) and subsequently transferred to $0.1 \mathrm{M}$ phosphate buffer solution (PBS). Animals were cryoanaesthetised in ice water prior to excision of the region containing the brain.

\section{Histological protocol}

Brains were dehydrated and embedded, following a protocol of ethanol series $(70,85,95$, and 100\%, 20 min each, last step two changes of $10 \mathrm{~min}$ each); $10 \mathrm{~min}$ in ethanol:xylene (1:1); $20 \mathrm{~min}$ (two changes) in xylene; $1^{\text {st }}$ infiltration in $58^{\circ} \mathrm{C}$ melting-point wax at $60^{\circ} \mathrm{C}(15 \mathrm{~min})$, and 2 nd infiltration for a further $15 \mathrm{~min}$. Tissue was oriented to allow horizontal sectioning, which permits the best view of the cell clusters (9 and 10) for $N$. granulata (Fonseca et al. 2005). Tissue was sectioned using a rotatory microtome set at $6 \mu \mathrm{m}$ section thickness. During sectioning, only sections containing the olfactory lobe, cell clusters, and the bundle of neurites linking cell clusters to the olfactory lobe were kept. Serial sections were collected and floated in a water bath $\left(40^{\circ} \mathrm{C}\right)$ to allow stretching, mounted onto a microscope slide, and allowed to dry overnight. Poly-L-lysine coated slides were used.

Immunohistochemical assays and image collection

In the immunohistochemical assays, the solution utilised for washing and also as a diluent was $0.1 \mathrm{M}$ PBS plus $0.3 \%$ Triton-X. All incubations at $37^{\circ} \mathrm{C}$ were carried out in a humidified chamber. Slides were dewaxed in xylene (10 min), rehydrated in an ethanol series $(100,95,85$, and $70 \%, 10 \mathrm{~min}$ each), and washed twice (30 min each).

In order to expose the epitopes, we performed the antigen recovery by heat shock using citrate buffer solution ( $0.01 \mathrm{~mol} / \mathrm{l}$ sodium citrate, $0.01 \mathrm{M}$ citric acid (1:1), and $0.01 \%$ Tween 20 , at $\mathrm{pH} 6$ ). Next, slides were incubated in $2 \mathrm{~mol} / 1 \mathrm{HCl}$ at $37^{\circ} \mathrm{C}$ for $20 \mathrm{~min}$ (DNA denaturation) followed by three washes of $0.1 \mathrm{M}$ PBS plus $0.3 \%$ Triton-X (10 min each). Slides were then incubated at $37^{\circ} \mathrm{C}$ with $5 \%$ goat serum (Sigma ${ }^{\circledR}$ G6767) for 30 min to block nonspecific antigens, and subsequently this solution was tapped. The next step was the application of the antibodies. Different sections of the same brain were utilised for each antibody assay (anti-BrdU and anti-ECR-A).

Monoclonal rat anti-BrdU (Abcam) (dilution 1:100) was added dropwise onto the sections. Sections were incubated overnight at $4^{\circ} \mathrm{C}$. After this incubation, slides were washed in three baths of $10 \mathrm{~min}$ each, and subsequently treated with anti-rat secondary antibody Alexa Fluor $^{\circledR} 488$ (Molecular Probes ${ }^{\circledR}$ A21123) (1:50) in room temperature (RT) in the dark, overnight.

For ecdysone receptors, mouse monoclonal antibody 15G1a (ECR-A) (Hybridoma Bank) (1:50) was added dropwise onto the sections and allowed to incubate overnight (RT). After this incubation, slides were washed in three baths of 10 min each, and subsequently treated with anti-mouse secondary monoclonal Alexa Fluor ${ }^{\circledR} 488$ (Molecular Probes ${ }^{\circledR}$ A21123) $(1: 200)$ at $4{ }^{\circ} \mathrm{C}$ in the dark, overnight.

Coverslips were mounted (in the dark) using Fluoromount. Slides were observed with a Zeiss Axioskop 2 Plus epifluorescence microscope with blue excitation filter $(550 \mathrm{~nm})$, at $40 \times$ magnification. Images of the appropriate region were captured using a Media Cybernetics, Evolution $^{\mathrm{TM}}$ model MP camera. After collection, each image was saved for further image analysis.

\section{Negative control}

Negative controls were processed as described above for the samples, except that primary antibodies were omitted. Instead, slides were incubated in the diluent only. 
Statistical analysis

The images obtained were arranged in the software Photoshop CS2, and the labelled cells were counted manually using the software ImageJ.

The variable analysed was the total number of observed cells marked with secondary antibody on both sides (right and left) of clusters in the central olfactory system. Data were expressed as mean \pm standard error. When the assumptions of variance homogeneity and normality were not met, log transformation was applied. One- and two-way ANOVAs were utilised, followed by a Tukey Test. The significance level adopted was $5 \%$.

\section{Results}

BrdU- and EcR-labelled cells were present in specific histological sections obtained from different depths of the brain. The majority of BrdU- and EcR-labelled cells occurred in clusters (9 and 10) in the central olfactory system of Neohelice granulata (Fig. 1).

The number of BrdU-labelled cells was higher $[F(1,17)=3.11, p<0.005]$ in winter $(138.2 \pm 21.5$, $n=13)$ than in summer $(68.5 \pm 6.3, n=22)$. However, the number of EcR-labelled cells was not significantly different $[F(1,15)=0.13, p>0.5$, after using a $t$ test $]$ between winter $(76.7 \pm 9.1, \quad n=12)$ and summer $(67.7 \pm 7.6, n=15)$ (Figs. 2, 3).

In winter, a significant effect of moult stage $[F(2$, $10=4.75, p<0.05]$ on the number of BrdU-labelled cells was apparent. Postmoult crabs $(247.3 \pm 45.9, n=3)$ showed more $(p<0.05)$ BrdU-labelled cells than premoult $(112.1 \pm 16.5, \quad n=7)$ and intermoult $(90.0 \pm 10.6$, $n=3$ ) (Fig. 4). In summer, no significant effect of moult stage $[F(2,19)=2.944, p=0.076]$ on the number of BrdU-labelled cells was observed (premoult was $63.2 \pm$ 6.2, $n=14$; intermoult was $53.8 \pm 12.9, n=4$; and postmoult was $102.0 \pm 16.6, n=4$ ) (Fig. 4a, c). However, in the two-way ANOVA analysis, the interaction between season and moult stage was not significant $[F(2$, 29) $=0.415, p=0.66]$.

Crabs collected in winter showed different numbers of EcR-labelled cells among moult stages $[F(2,9)=4.851$, $p<0.05]$. Premoult crabs $(102.4 \pm 13.5, n=5)$ showed more cells than postmoult crabs $(56.4 \pm 11.3, n=4$, $p<0.05$ ), but not significantly different from intermoult $(61.0 \pm 4.4, n=3, p>0.1)$. In summer, moult stage did not significantly affect the number of EcR-labelled cells $[F(2,13)=2.62, \quad p>0.1] . \quad$ EcR-labelled cells were similar in premoult $(80.7 \pm 10.8, n=9)$, intermoult $(56.0 \pm 9.6, n=3)$, and postmoult $(47.3 \pm 10.8, n=4)$ crabs (Fig. 4b, d), as assayed by one-way ANOVA.

\section{Discussion}

A number of factors including environmental richness (Kempermann and Gage 1999; Scotto-Lomassese et al. 2000), circadian rhythms (Goergem et al. 2002), and ontogeny (Beltz and Sandeman 2003) influence the proliferation of nerve cells in adult decapods. These observations suggest that the continuous proliferation of nerve cells in adult crustaceans is well regulated to adjust to the animals' requirements.
Fig. 1 Supraesophageal ganglion of Neohelice granulata showing the locations of BrdUlabelled cells (a) and of EcRlabelled cells (b). $O L$ olfactory lobe, $C M 10$ cell mass $10, C M 9$ cell mass 9. Scale bar $100 \mu \mathrm{m}$
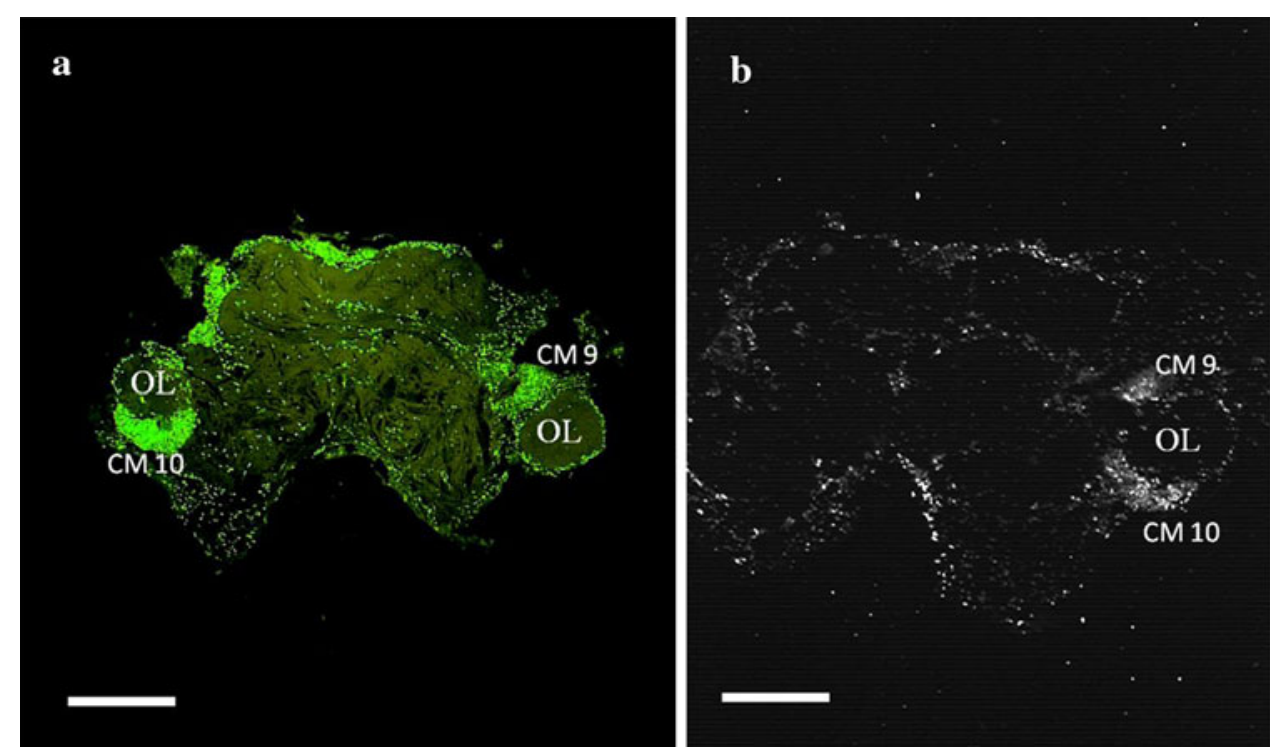
Fig. 2 Images of clusters of central olfactory system of Neohelice granulata of crabs in premoult. a BrdU-labelled cells in winter. The inset shows the labelled cells in a higher magnification. b BrdU-labelled cells in summer. c Negative control of BrdU-labelled cells. d EcR-labelled cells in winter. e EcR-labelled cells in summer. The inset shows the labelled cells in a higher magnification. f Negative control of EcRlabelled cells. $O L$ olfactory lobe, $C M 10$ cell mass $10, C M 9$ cell mass 9. Scale bar $20 \mu \mathrm{m}$; insets in a and d $10 \mu \mathrm{m}$
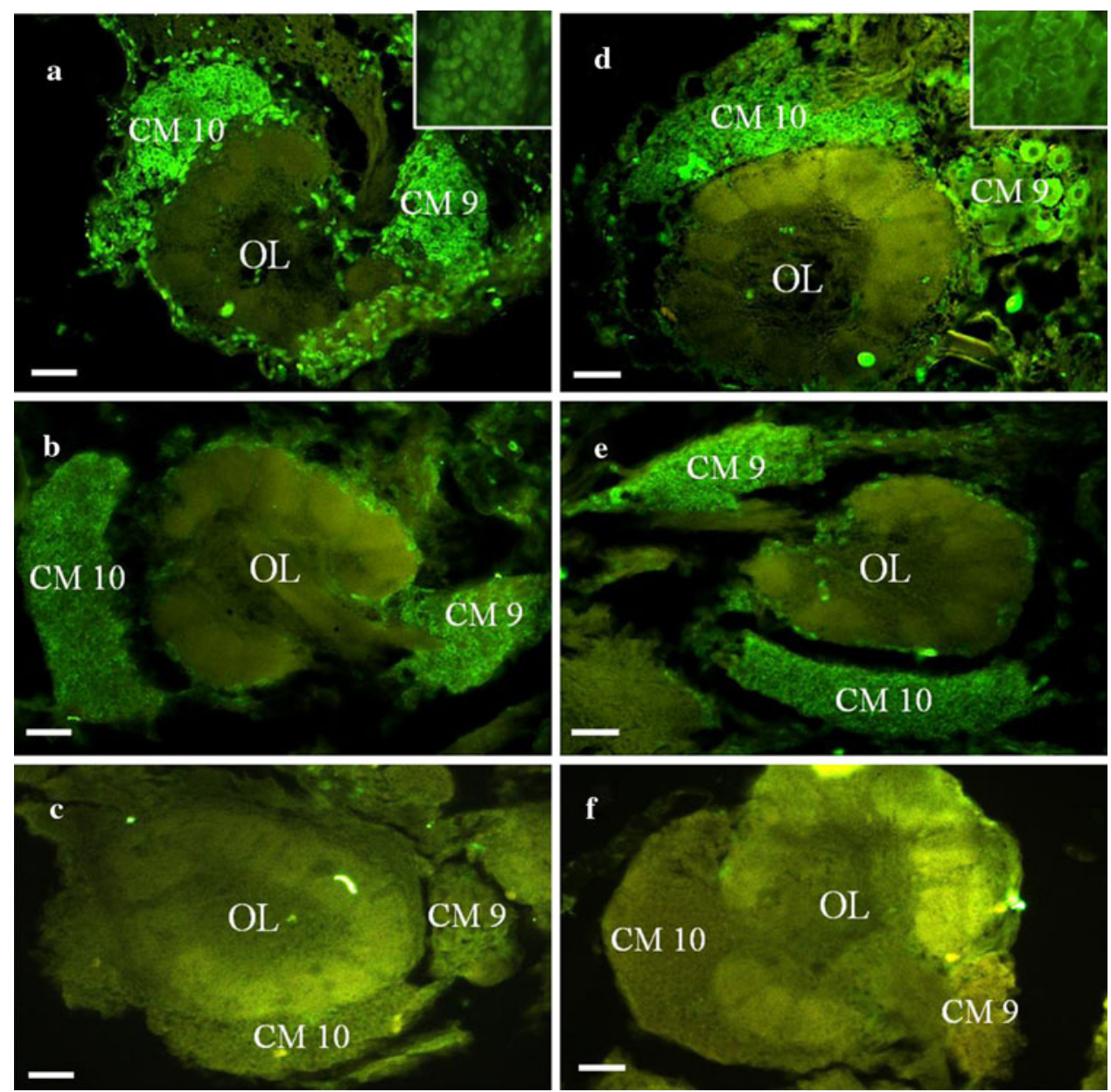

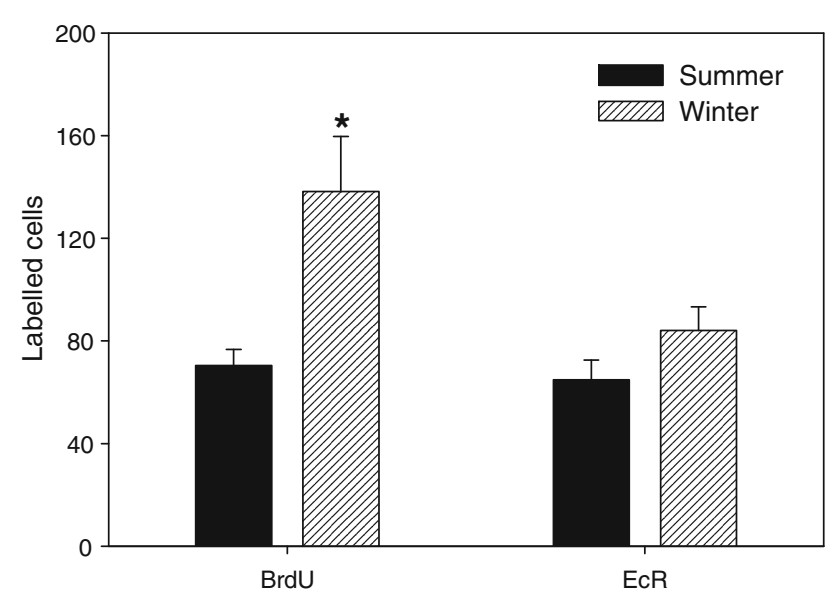

Fig. 3 Average of BrdU-labelled cells and EcR-labelled cells in clusters of central olfactory system of Neohelice granulata in crabs caught in winter and summer. Data are mean \pm standard error, with $0.05 \%$ significance level. Asterisk indicates statistical difference

\section{Seasonality}

Information on the effects of seasonality on the proliferation of nerve cells in decapods is scarce. A single study published (Hansen and Schimidt 2004) on the crab Carcinus maenas reported a seasonal difference (higher in spring and late summer) in the number of proliferative cells in clusters of the central olfactory system. However, this difference was observed only when the effect of the size of the crab was disregarded, as a covariance analysis using a general linear model indicated no significant effect of the categorical variable time of year. Therefore, the reported seasonal difference was confounded with the effect of size, because crab size was not controlled in the investigation. For instance, there was a likely statistical difference in the size of the crabs (35\% smaller in spring) caught in the months in which the highest and the lowest number of BrdU-positive cells were found (Hansen and Schimidt 2004, Table 1a). The results of the present investigation arguably demonstrated a difference between seasons, because the size of the crabs was controlled and no statistical difference ( $t$ test, $p=0.13$ ) was found between crabs caught in summer (mean LC \pm S.E. $=18.6 \pm$ $1.0 \mathrm{~mm})$ and in winter $(17.8 \pm 1.0 \mathrm{~mm})$. However, the difference found was the opposite of that expected, as many physiological processes are enhanced in the higher temperatures in spring/summer, and Neohelice granulata 
Fig. 4 a Mean number of BrdU-labelled cells in clusters of central olfactory system in moult stages (premoult, postmoult, and intermoult) in winter. b Average of EcRlabelled cells in clusters of central olfactory system in moult stages (premoult, postmoult, and intermoult) in winter. c Average of BrdUlabelled cells in clusters of central olfactory system in moult stages (premoult, postmoult, and intermoult) in summer. d Average of EcRlabelled cells in clusters of central olfactory system in moult stages (premoult, postmoult, and intermoult) in summer. Data are

mean \pm standard error with $0.05 \%$ significance level. Equal letters indicate $p>0.05$, and different letters indicate $p<0.05$
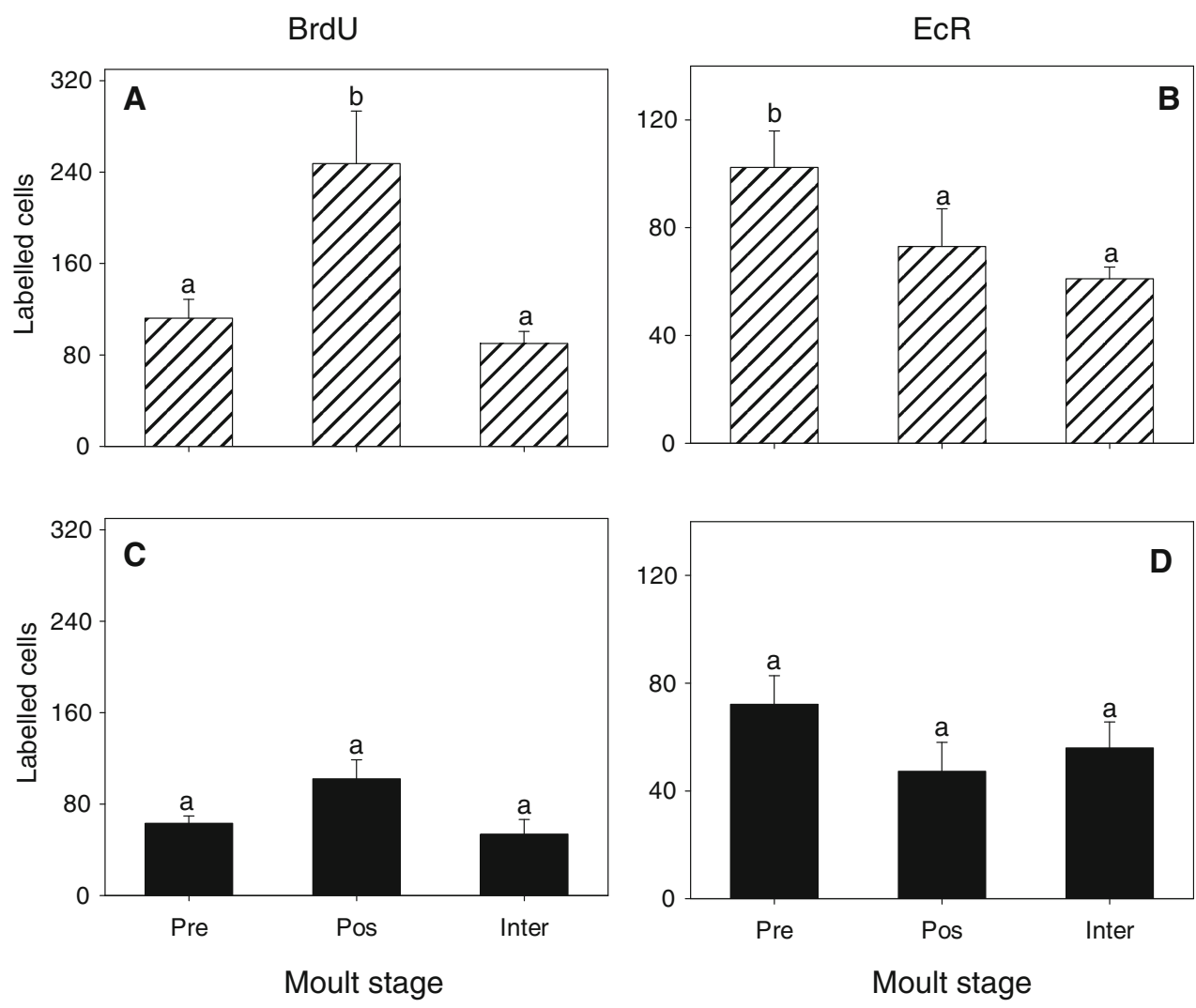

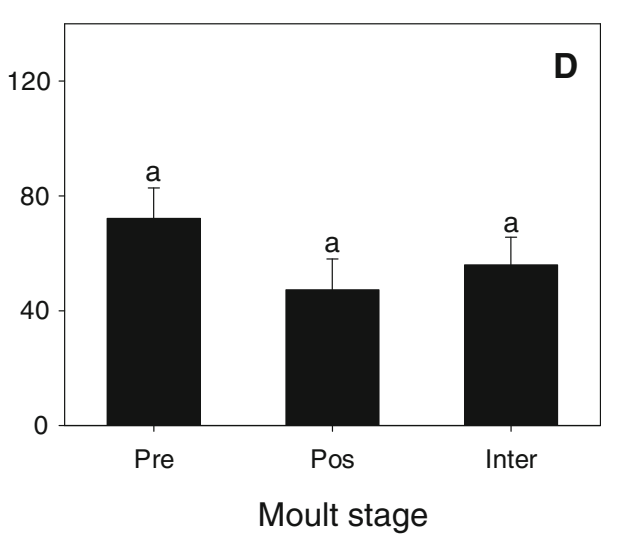

clearly shows more intense growth and reproduction in spring/summer (Bas et al. 2009; Barutot et al. 2009). At this stage, any explanation for the observed higher proliferation rate in winter is merely speculative, but this first evidence of a difference between seasons cannot be ignored.

One possibility is that the proliferation process is tightly regulated according to endogenous requirements that do not necessarily depend on temperature. Reproduction occurs during the intermoult stage, which can last for an extended period depending on physiological conditions, and is characterised by low levels of circulating ecdysteroids (Hopkins 1992). Males and females allocate most of their energy to the reproductive process, and assuming a finite pool of energetic resources, a trade-off is required between allocation to reproduction and allocation to somatic maintenance (Calow 1983). N. granulata typically reproduces in spring and summer (Barutot et al. 2009). Therefore, during winter, crabs probably have more energy to expend on other processes, such as proliferation.

The variation in size of $N$. granulata is characterised by a period without changes in winter (D'Incao et al. 1993), indicating a slower growth rate and probably fewer moults in this season than in summer. The absence of a significant variation in the number of EcR-labelled cells in the cluster of the central olfactory system of $N$. granulata between winter and summer could be explained by two hypotheses.
The first is that, despite the fact that there is no difference in the number of EcR-labelled cells, there may be a difference in the total number of receptors. The labelling of a cell does not indicate that there is a specific number of receptors, but that there are receptors being expressed. Another hypothesis is that, although there is an expected increase of the ecdysteroid hormone during the premoult, the number of EcR-labelled cells may be similar in all stages of the moult cycles. We cannot ignore the fact that the increase in the hormone level is accompanied by an increase of its receptor, but, in this case, the amount of EcR labelling should be constant in the cells and should not change with the hormone levels.

\section{Moult cycle}

In addition to the effect of seasonal variation on the proliferation of nerve cells of the clusters of the central olfactory system, cell proliferation also varied during the moult cycle. In the crayfish Cherax destructor, the number of BrdU-labelled cells in clusters of the brain revealed that the rate of cell proliferation also changes in relation to the stage of the moult cycle (Gorissen 2002). This author observed a sudden decrease in the proliferation rate shortly before the moult, followed by a recovery in early postmoult. In the present investigation, a similar pattern was found, in which the number of proliferating nerve cells was 
significantly higher in postmoult (winter) than in premoult and intermoult. During the postmoult, crustaceans have the highest number of cells in mitosis in their tissues, possibly as a consequence of the increase in body size in this period. The volumes of the cell clusters increase linearly with the size of the animal, indicating that new cells are added to these cell clusters throughout the lifespan of the animals (Beltz and Sandeman 2003). New olfactory receptor neurones (ORNs) are added as the surface area of the animal's body increases. These new ORNs, which proliferate more rapidly during premoult (Harrison et al. 2001), project afferent axons into the central nervous system. The axons establish synaptic contacts with new projection neurones of the olfactory lobe cell mass (cluster 10) in the glomerular region of the olfactory lobe (Sandeman 1982; Laverack 1988). As a result, the overall size of the brain, particularly of the olfactory region, increases.

Levels of total ecdysteroids in the haemolymph of crustaceans remain very low during intermoult, when the animals are feeding and mating. Ecdysteroid levels rise rapidly as crustaceans approach the moult, and then abruptly fall just prior to the moult itself (Hopkins 1992; Nakatsuji and Sonobe 2004). The expression of ecdysone receptors increases in premoult (Chung et al. 1999). The data from the present investigation showed higher numbers of EcR-labelled cells in premoult than in postmoult and intermoult in winter, indicating that in this species, at least, a concomitant increase of EcR-expressing nerve cells occurs with the increase of ecdysteroid levels. As pointed out earlier, it is not necessarily true that an increase in the levels of the ecdysteroid hormone would be mirrored by an increase in the number of receptors. It is not yet known how the production of central interneurons and receptor cells is coordinated during the moult cycle. It is known that ecdysteroids play a role in the moult cycle and growth of crustaceans, but the possible effect of ecdysteroids on the proliferation of nerve cells remains poorly documented. Thus, how the seasonal variations influence the proliferation of nerve cells, how the ecdysone receptors are distributed during the moult cycle, and the possible relation between the proliferation of nerve cells and ecdysone receptors are not well understood. In conclusion, the proliferation of the central olfactory system of Neohelice granulata changes during the moult cycle and the seasons, indicating that this process is regulated in this species. The possibility of direct involvement of EcR in this process needs to be clarified.

Acknowledgments This research was supported by the Conselho Nacional de Desenvolvimento Científico e Tecnológico (CNPq), Proc. No 484683/2007. Luiz Eduardo Maia Nery, Silvana Allodi, and Duane Barros Fonseca are research fellows of the Brazilian CNPq. Gabriela Hollmann received a graduate fellowship from the Brazilian agency CAPES.

\section{References}

Barutot RA, D'Incao F, Fonseca DB (2009) Reproductive biology of Neohelice granulata (Decapoda: Varunidae) in two salt marshes of the estuarine region of the Patos Lagoon, southern Brazil. J Mar Biol Assoc UK 89:769-774

Bas C, Luppi T, Spivak E, Schejter L (2009) Larval dispersion of the estuarine crab Neohelice granulata in coastal marine waters of the Southwest Atlantic. Estuar Coast Shelf Sci 83:569-576

Beltz BS, Sandeman DC (2003) Regulation of life-long neurogenesis in the decapod crustacean brain. Arthropod Struct Dev 32:39-60

Calow PC (1983) Energetics of reproduction and its evolutionary implications. Biol J Linn Soc 20:153-165

Cesar JRO, Zhao B, Malecha S, Ako H, Yang J (2006) Morphological and biochemical changes in the muscle of the marine shrimp Litopenaeus vannamei during the molt cycle. Aquaculture 261:688-694

Chan SM, Rankin SM, Keeley LL (1988) Characterization of the moult stages in Penaeus vannamei: setogenesis and hemolymph levels of total protein, ecdysteroids and glucose. Biol Bull 175:185-192

Chang ES, Kaufman RW (2005) Endocrinology of crustacea and chelicerata. In: Gilbert LJ (ed) Comprehensive molecular insect science. Elsevier, Amsterdam, Pergamon, pp 805-842

Chung ACK, Durica DS, Hopkins PM (1998) Tissue-specific patterns and steady-state concentrations of ecdysteroid receptor and retinoid-X-receptor mRNA during the molt cycle of the fiddler crab, Uca pugilator. Gen Comp Endocrinol 109:375-389

Chung JS, Dircksen H, Webster SG (1999) A remarkable, precisely timed release of hyperglycemic hormone from endocrine cells in the gut is associated with ecdysis in the crab Carcinus maenas. Proc Natl Acad Sci USA 6:13103-13107

D'Incao F, Ruffino ML, Silva KG, Costa Braga A (1993) Responses of Chasmagnathus granulata Dana (Decapoda: Grapsidae) to saltmarsh environmental variations. J Exp Mar Biol Ecol 161:179-188

Emsley JG, Mitchell BD, Kempermann G, Macklis JD (2005) Adult neurogenesis and repair of the adult CNS with neural progenitors, precursors, and stem cells. Prog Neurobiol 75:321-341

Fonseca DB, Parise CK, Barutot RA, D'Incao F (2005) Occurrence of lipofuscin age pigment in Chasmagnathus granulatus (Decapoda, Varunidae). Nauplius 13:175-181

Goergem EM, Bagay LA, Rehm K, Benton JL, Beltz BS (2002) Circadian control of neurogenesis. J Neurobiol 53:90-95

Gorissen S (2002) Endogenous control of neurogenesis in the juvenile crayfish brain. Thesis, University of New South Wales, Sydney, Australia. Op sit in Sandeman DC, Beltz B (2003) Regulation of life-long neurogenesis in the decapod crustacean brain. Arthropod Struct Dev 32:39-60

Hansen A, Schimidt M (2004) Influence of season and environment on adult neurogenesis in the central olfactory pathway of the shore crab, Carcinus maenas. Brain Res 1025:85-97

Harrison PJH, Cate HS, Swanson ES, Derby CD (2001) Postembryonic proliferation in the spiny lobster antennular epithelium: rate of genesis of olfactory receptor neurons is dependent on molt stage. J Neurobiol 47:51-66

Herman MH, Miquel J, Johnson M (1971) Insect brain as a model for the study of aging. Acta Neuropath 19:167-183

Hopkins PM (1992) Hormonal control of the molt cycle in the fiddler crab, Uca pugilator. Am Zool 32:450-458

Horner AJ, Nduku V, Vu V, Harrison PJH, Derby CD (2003) Circadian rhythmicity to neurogenesis in the olfactory organ and brain of spiny lobsters. Achems Abstr 25:6

Kempermann G, Gage FH (1999) New nerve cells for the adult brain. Sci Am 280:48-53 
Laverack MS (1988) The numbers of neurones in decapod Crustacea. J Crust Biol 8:1-11

Mattson MP, Chan SL, Duan W (2002) Modification of brain aging and neurodegenerative disorders by genes, diet, and behavior. Physiol Rev 82:637-672

Mellon D, Alones V (1993) Cellular organization and growth related plasticity of the crayfish olfactory midbrain. Microsc Res Tech 24:231-259

Monserrat J, Bianchini A (1995) Effects of temperature and salinity on the toxicity of a commercial formulation of methyl parathion to Chasmagnathus granulata (Decapoda, Grapsidae). Braz J Med Biol Res 28:74-78

Nakagawa Y, Henrich VC (2009) Arthropod nuclear receptors and their role in molting. J FEBS 276:6128-6157

Nakatsuji T, Sonobe H (2004) Regulation of ecdysteroid secretion from the Y-organ by molt-inhibiting hormone in the American crayfish, Procambarus clarkii. Gen Comp Endocrinol 135:358364

Rockstein M (1950) The relation of cholinesterase activity to change in cell number with age in the brain of the adult honeybee. J Cell Comp Physiol 35:11-24

Sandeman DC (1982) Organization of the Central Nervous System. In: Atwood HA, Sandeman DC (eds) Biology of the crustacea, 3rd edn. Academic Press, New York, pp 1-54

Schmidt M, Harzsch S (1999) Comparative analysis of neurogenesis in the central olfactory pathway of adult decapod crustaceans by in vivo BrdU labeling. Biol Bull 196:127-136
Scotto-Lomassese S, Strambi C, Strambi A, Charpin P, Augier R, Aouane A, Cayre M (2000) Influence of environmental stimulation on neurogenesis in the adult insect brain. J Neurobiol 45:162-171

Sohal RS (1983) Chapter 18: aging in insects. In: Kerkut GA, Gilbert LI (eds) Comprehensive insect physiology, biochemistry and pharmacology, vol 10. pergamon press, Oxford, pp 595-631

Sohal RS, Sharma SP (1972) Age-related changes in the fine structure and number of neurons in the brain of the housefly, Musca domestica. Exp Gerontol 7:243-249

Soumoff C, Skinner DM (1983) Stress reduces hemolymph ecdysteroid levels in the crab: Mediation by the eyestalks. J Exp Zool 234:319-323

Spaziani E, Jegla TC, Wang WL, Booth JA, Connolly SM, Conrad CC, Dewall MJ, Sarno CM, Stone DK, Montgomery R (2001) Further studies on signaling pathways for ecdysteroidogenesis in crustacean Y-organs. Amer Zool 41:418-429

Sullivan J, Beltz B (2001) Neural pathways connecting the deutocerebrum and lateral protocerebrum in the brains of decapod crustaceans. J Comp Neurol 441:9-22

Sullivan JM, Beltz BS (2005) Newborn cells in the adult crayfish brain differentiate into distinct neuronal types. J Neurobiol 65:157-170

Tummel CS (1995) From embryogenesis to metamorphosis: the regulation and function of Drosophila nuclear receptor superfamily members. Cell 83:871-877 